\title{
Hypo-hyperdontia: a case report
}

\author{
Hipo-hiperdontia: relato de caso
}

Henrique Castilhos RUSCHEL

Michelle DIAMANTE'

Paulo Floriani KRAMER'

\begin{abstract}
The occurrence of hypodontia (absence of teeth) and hyperdontia (presence of supernumerary teeth) in the same patient is a rarely seen condition in dental practice. Early diagnosis and adequate treatment are very important when addressing this abnormality in the mixed dentition. The approach will depend on the severity of the case and the timing of diagnosis. This paper reports the case of an 11-year-old patient with absence of the permanent maxillary lateral incisors and the mandibular second premolars, with concomitant presence of a supernumerary tooth in the region of the right mandibular lateral incisor. Based on physical and radiographic examination findings, a diagnosis of hypo-hyperdontia was made. The diagnostic and therapeutic management of the case is discussed. The treatment adopted was surgical removal of the supernumerary teeth and esthetic restoration to transform the permanent mandibular canines into lateral incisors.
\end{abstract}

Indexing terms: Anodontia. Tooth abnormalities. Tooth, supernumerary.

\section{RESUMO}

A ocorrência de hipodontia - ausência de dentes - e hiperdontia - presença de dentes a mais - em um mesmo paciente é uma condição pouco freqüente na clínica odontológica. O diagnóstico precoce e a realização de um tratamento adequado são muito importantes para a abordagem deste tipo de anomalia na dentição mista. A abordagem dependerá da complexidade de cada caso e do momento de diagnóstico da condição. Nesse artigo é relatado um caso de uma paciente com 11 anos de idade com a ausência dos incisivos laterais permanentes superiores e dos segundos pré-molares inferiores, concomitante com a presença de um dente supranumerário na região de incisivo lateral superior direito. Com base no exame físico e radiográfico chegou-se ao diagnóstico de hipo-hiperdontia. As condutas para o diagnóstico e tratamento do caso são abordadas e discutidas. O tratamento adotado foi a remoção do dente supranumerário e a transformação estética dos caninos permanentes superiores em incisivos laterais.

Termos de indexação: Anodontia. Anormalidades dentárias. Dente supranumerário.

\section{INTRODUCTION}

Hypodontia, characterized by the congenital absence of one or more teeth, is the most prevalent developmental anomaly. This abnormality may involve both the deciduous and the permanent teeth, and may be unilateral or bilateral1-6. Hypodontia is the result of disruption or obstruction of the dental lamina during the early stages of embryogenesis, caused by local, systemic, or genetic factors ${ }^{3}$.

Hypodontia is only rarely observed in the primary teeth, with a prevalence of $0.1 \%$ to $0.9 \%$ and no significant gender difference ${ }^{2,4-5,7}$. It is more common in the permanent dentition, with a prevalence of $3 \%$ to $7 \%$, excluding the third molars, and affects women more commonly, at a 3:2 female-to-male ratio ${ }^{1,2,8-10}$. The teeth most often affected, in descending frequency, are the maxillary lateral incisors (37\%), the mandibular second premolars $(32.26 \%)$, and the maxillary second premolars $(17.74 \%)$, excluding the third molars $6,10-11$.

Hyperdontia, or supernumerary teeth, are defined as the presence of one or more teeth in addition to the regular series. The supernumerary tooth is classified in accordance with its position in the dental arch as mesiodens, paramolar, or distomolar, and may be impacted ${ }^{1,2,11-12}$. Hyperdontia is the result of abnormal continuous activity of the dental lamina, which leads to the formation of additional tooth buds. Its etiology is multifactorial, although a strong genetic pattern is involved ${ }^{3,13-14}$.

Hyperdontia most commonly affects the permanent teeth, at a 1:5 ratio; in 30\% of cases, it occurs in both dentitions ${ }^{1-2}$. It is more prevalent in men, with a

\footnotetext{
${ }^{1}$ Universidade Luterana do Brasil, Curso de Odontologia. Av. Farroupilha, 8001, São José, 92425-900, Canoas, RS, Brasil. Correspondência para / Correspondence to: HC RUSCHEL. E-mail: <henrirus@gmail.com>.
} 
2:1 male-to-female predominance $e^{1-3,13}$. Supernumerary teeth are most commonly found in the maxilla, with a particular predilection for the premaxilla. Such a tooth is known as a mesiodens, and represents the most prevalent form of hyperdontia, accounting for $45 \%$ to $67 \%$ of all supernumerary teeth. In descending order of frequency, mesiodens are followed by paramolars, distomolars (also known as fourth molars), premolars, and lateral incisors. Overall, $75 \%$ of supernumerary teeth are impacted, and are only diagnosed on radiographic examination ${ }^{1-3,11,13,15}$.

Supernumerary teeth may be normal in shape or anomalous; the latter can cause complications such as delayed eruption of adjacent teeth, or esthetic and functional problems $s^{1,3,13}$.
The concomitant presence of a supernumerary tooth and hypodontia in the same individual is a rare condition. In 1967, Camilleri'16 defined this situation as "concomitant hypodontia and hyperdontia", and in 1979, Gibson ${ }^{7}$ adopted the term "hypo-hyperdontia".

Differences in sampling criteria, diagnosis, and ethnicity have led to variations in the reported prevalence of hypo-hyperdontia. Gibson ${ }^{7}$ found 20 cases of hypohyperdontia in a sample of 4,598 individuals, for a prevalence of $0.4 \%$. Of these 20 cases, 13 exhibited involvement of both arches, which the author termed bimaxillary hypo-hyperdontia. Table 1 presents some studies on the prevalence of hypo-hyperdontia, and Table 2 lists some cases described in the literature.

Table 1. Published studies on the prevalence of concomitant hypo-hyperdontia.

\begin{tabular}{cccc}
\hline Study & Sample $(\mathbf{n})$ & Number of cases & Prevalence \\
\hline Werther \& Rothenberg $^{17}$ & 1.000 & 7 & $0.7 \%$ \\
Niswander \& Sujaku $^{18}$ & 4.150 & 5 & $0.12 \%$ \\
Horowitz $^{19}$ & 1.000 & 1 & $0.1 \%$ \\
Novak $^{20}$ & 161 & 5 & $3.1 \%$ \\
Gibson $^{7}$ & 4.595 & 20 & $0.43 \%$ \\
Davis $^{21}$ & 1.093 & 4 & $0.36 \%$ \\
Tyrologou et al. 22 & 11.500 & 3 & $0.02 \%$ \\
\hline
\end{tabular}

Table 2. Cases of concomitant hypo-hyperdontia of the permanent dentition reported in the literature.

\begin{tabular}{|c|c|c|}
\hline Study & Hypodontia & Location of supernumerary tooth \\
\hline Camilleri16 & Maxillary lateral incisors & Mesiodens \\
\hline Low $^{23}$ & Mandibular central incisors & Mandibular mesiodens \\
\hline Spyropoulos et al. ${ }^{11}$ & $\begin{array}{l}\text { Maxillary lateral incisors } \\
\text { Maxillary 1st and 2nd premolars } \\
\text { Right mandibular 1st premolar } \\
\text { Mandibular 2nd premolars } \\
\text { Left mandibular 2nd molar }\end{array}$ & Region of mandibular incisors \\
\hline \multirow[t]{2}{*}{ (3 cases) } & $\begin{array}{l}\text { Right maxillary canine } \\
\text { Right mandibular 2nd premolar }\end{array}$ & Mesiodens \\
\hline & Left mandibular central incisor & Region of left maxillary lateral incisor \\
\hline Moore ${ }^{24}$ & Maxillary canines & Region of right maxillary lateral incisor \\
\hline Zhu et al. ${ }^{2}$ & Maxillary lateral incisors & Region of right mandibular 1st molar \\
\hline Segura \& Jimezez-Rubio ${ }^{13}$ & Left maxillary lateral incisor & Mesiodens \\
\hline Matsumoto et al. ${ }^{15}$ & $\begin{array}{l}\text { Left mandibular lateral incisor } \\
\text { Left maxillary } 2 \text { nd premolar }\end{array}$ & Region of left maxillary lateral incisor \\
\hline Sharma ${ }^{25}$ & Left maxillary canine & $\begin{array}{l}\text { Region of left lateral incisor, maxillary central } \\
\text { incisors and mandibular lateral incisors }\end{array}$ \\
\hline \multirow{4}{*}{ Anthonappa et al. ${ }^{26}$} & Mandibular central incisors & Region of left maxillary canine \\
\hline & $\begin{array}{l}\text { Right maxillary 2nd premolar } \\
\text { Left mandibular } 2 \text { nd premolar }\end{array}$ & Region of left maxillary central incisor \\
\hline & Left mandibular lateral incisor & Region of right maxillary 2 nd premolar \\
\hline & $\begin{array}{l}\text { Mandibular central incisors (deciduous) } \\
\text { Right mandibular lateral incisor }\end{array}$ & Mesiodens \\
\hline \multirow[t]{3}{*}{ (7 cases) } & Mandibular central incisors & Region of maxillary central incisors \\
\hline & $\begin{array}{l}\text { Left mandibular lateral incisor (deciduous) } \\
\text { Left mandibular lateral incisor }\end{array}$ & Region of left maxillary central incisor \\
\hline & Mandibular 2nd premolars & Mesiodens \\
\hline
\end{tabular}


The present article seeks to report the case of a patient with congenital absence of the permanent maxillary lateral incisors and mandibular second premolars, with concomitant presence of a supernumerary tooth in the region of the absent right maxillary lateral incisor. In addition, this article also aims to describe a proposal for surgical and esthetic rehabilitation of the reported case of hypo-hyperdontia.

\section{CASE REPORT}

An 11-year-old girl presented with her mother with a complaint of "some teeth not appearing after the corresponding baby teeth had been lost". Prior and current medical and family history were considered normal, and did not appear to correlate with the reported clinical picture.

There were no extraoral abnormalities on physical examination. Intraoral examination revealed absence of the deciduous left maxillary lateral incisor and presence of the homologous tooth. Examination of the mandibular arch revealed absence of the primary left second molar and non-eruption of the corresponding second premolar, whereas the primary right second molar was present. In addition, carious lesions were found in some teeth, and occlusal examination revealed a left posterior crossbite (Figure 1).

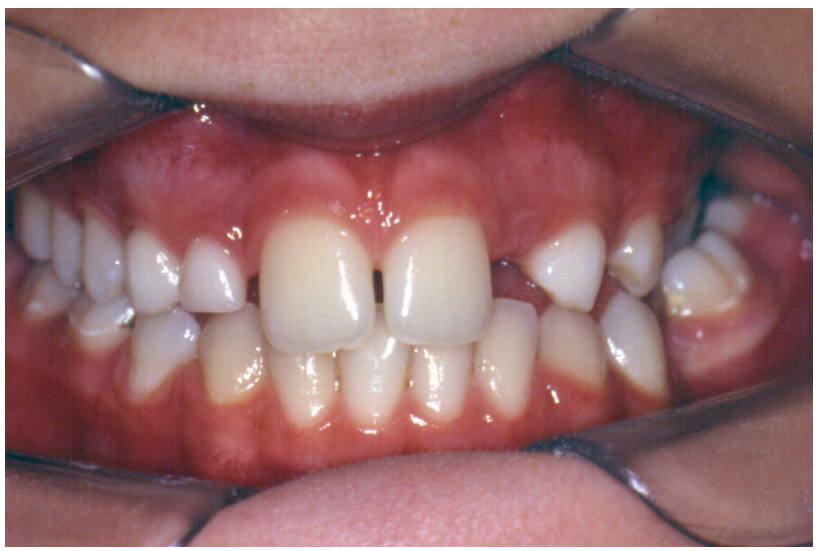

Figure 1. Initial clinical appearance, demonstrating absence of the primary left maxillary lateral incisor and prolonged retention of the homologous primary lateral incisor.

Periapical radiographs of the region of the maxillary lateral incisors confirmed absence of the permanent lateral incisors and presence of a tooth with anomalous crown and root morphology in the region of the right lateral incisor, consistent with a supernumerary tooth. A panoramic radiograph was obtained for diagnostic confirmation and to ascertain whether there was agenesis of other teeth. The panoramic radiograph confirmed previous diagnostic findings for the anteriorsuperior region and revealed that the mandibular second premolars were also absent (Figure 2).

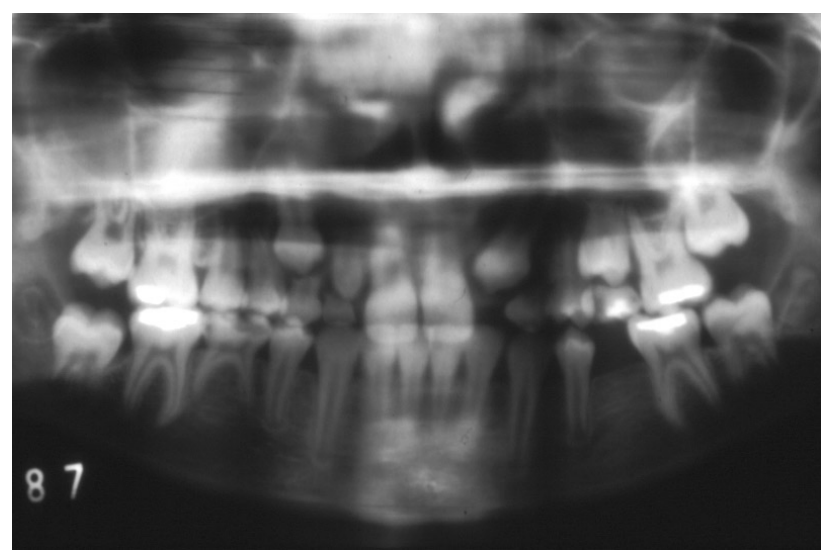

Figure 2. Panoramic radiograph confirming absence of the permanent maxillary lateral incisors, presence of a supernumerary tooth in the region of the right maxillary lateral incisor, and absence of the mandibular second premolars.

Based on these physical and radiographic examination findings, a diagnosis of anomaly of tooth number was made. The patient presented partial anodontia with concomitant presence of a supernumerary tooth, thus characterizing hypo-hyperdontia of the permanent dentition.

The treatment strategy initially proposed for this patient consisted of adhesive composite-resin restoration of the carious teeth, followed by surgical extraction of the supernumerary teeth, the primary maxillary canines, and the primary right maxillary lateral incisor. All surgical extractions were performed in a single visit (Figure 3).

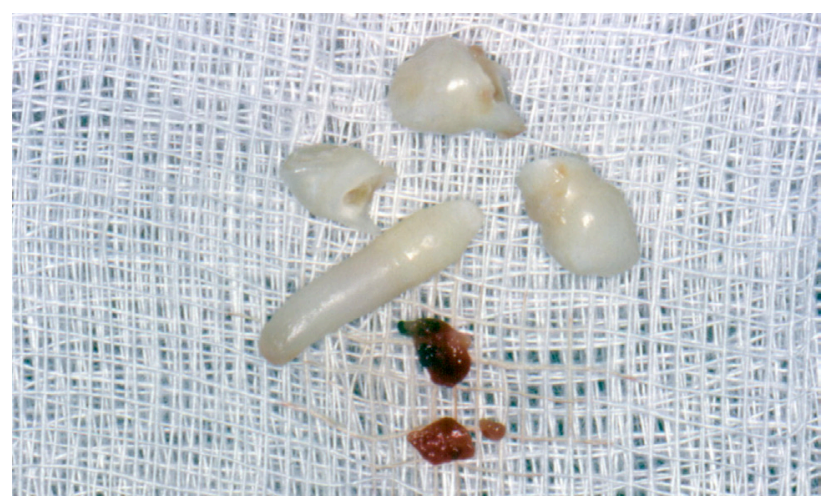

Figure 3. Extracted teeth (deciduous right maxillary lateral incisor, deciduous maxillary canines, and supernumerary tooth). 
During follow-up and case planning, esthetic transformation of the maxillary canines into lateral incisors after orthodontic treatment was proposed. The patient's mother stated she was unable to pay for the proposed treatment at the time and inquired about the possibility of immediate esthetic repair. Therefore, we chose to await complete eruption of the canines before transformation. Figure 4 shows the canines erupted into the maxillary arch.

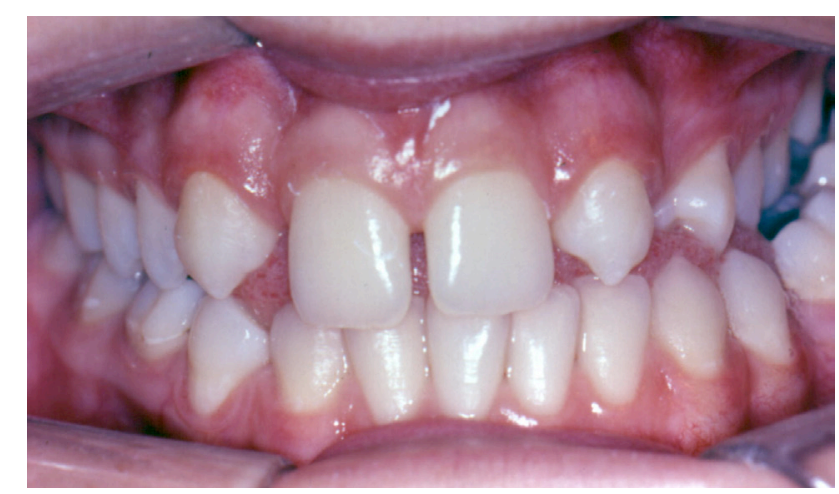

Figure 4. Permanent maxillary canines after complete eruption.

Transformation of the canines into lateral incisors was performed under rubber dam isolation, with clamps placed on the maxillary first premolars bilaterally, and floss ligatures on the canines and central incisors. The canines were modified by wearing down the mesial, distal, and buccal surfaces to obtain enough space for composite resin buildup, seeking a satisfactory esthetic outcome (Figure 5). The enamel was worn down with a high-speed diamond cross-cut fissure bur, under irrigation. After restoration of both teeth had been completed, the dams were removed and final adjustments performed. Figure 6 shows the patient's smile after finishing and polishing of restorations, 1 week after the procedure.

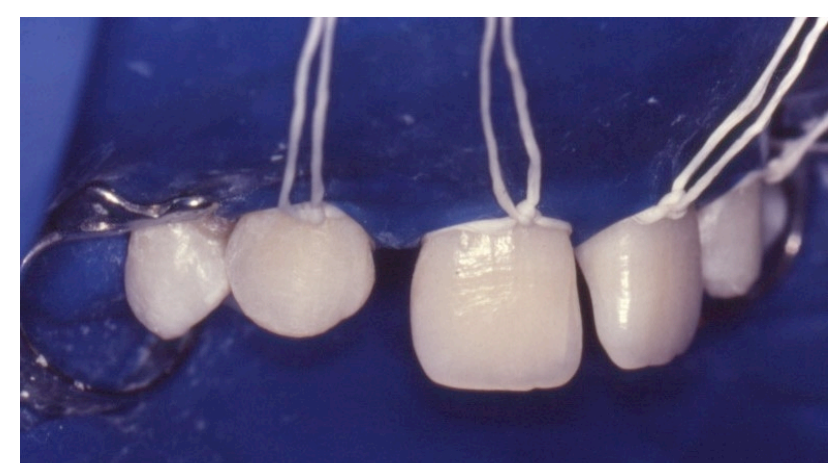

Figure 5. Wearing of the proximal and buccal aspects of the canines prior to composite resin restoration.

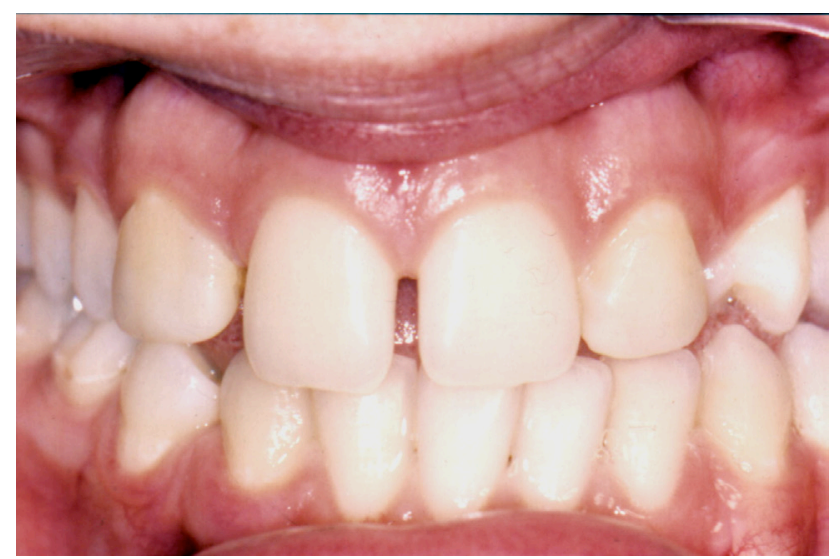

Figure 6. Final appearance, after esthetic transformation of the maxillary canines into lateral incisors.

After this stage, the patient's mother was once again reminded of the importance of orthodontic evaluation to establish further treatment planning, in view of the absence of the mandibular second premolars and presence of posterior crossbite.

This case report complies with the applicable ethical principles. The patient is not identifiable and authorization was obtained from the patient's legal guardian to publish the case and all images contained in this article.

\section{DISCUSSION}

Concomitant hypodontia and hyperdontia is a rare condition. According to the literature, the prevalence of this anomaly ranges from $0.02 \% 3.1 \%^{20,22}$, and may be as low as $0.002 \%^{26}$. Furthermore, although the isolated forms of this anomaly (hypodontia and hyperdontia) are associated with differences of prevalence between the male and female sexes, hypo-hyperdontia tends to present no such distinction ${ }^{26}$.

The etiology of this anomaly is unknown; suggested causes include disorders of migration, proliferation, and differentiation of neural crest cells and interaction between mesenchymal and epithelial cells during the initial stage of odontogenesis ${ }^{2,27}$.

Various types of combinations have been reported in cases of hypo-hyperdontia, but the occurrence of a supernumerary tooth in the premaxillary region, as in the case reported herein, is quite a common condition. Agenesis of the maxillary lateral incisors and mandibular second premolars are also common manifestations $2,11,13,16,26$.

The presence of a supernumerary tooth and congenital absence of another tooth may lead 
to esthetic and functional issues. If impacted, the supernumerary tooth may delay eruption of adjacent teeth. If the adjacent teeth have already erupted, functional and esthetic problems may result 2,3,13-15. The absence of one or more teeth can occur in disorders such as deciduous tooth retention, ectopic eruption of other teeth, and crowding $2,4,9$. Congenital absence is suspected when the timing and/or sequence of tooth eruption is altered, exfoliation is delayed, or there is ankylosis of the deciduous teeth ${ }^{10,28}$. In the case described herein, despite the age of the patient, she exhibited no eruption of the permanent maxillary lateral incisors, as well as prolonged retention of one of the deciduous lateral incisors.

The treatment of choice is based on factors such as presenting complaint, patient opinion, patient profile, availability of space, and amount of space closure required. Patient age must also be taken into account ${ }^{10}$. The primary role of treatment is to replace the missing tooth and improve the patient's appearance, speech, and masticatory efficiency ${ }^{8}$. In the case described in the present report, the interests of the patient and her guardian were met, and their search for the most esthetic and functional outcome possible was achieved.

Treatment requires careful planning and decisionmaking. If the supernumerary tooth is the cause of complications, it should ideally be extracted ${ }^{3,13}$. Some of the factors that influence treatment planning include patient age, number of retained teeth, number of missing teeth, condition of supporting bone, occlusion, and interocclusal space ${ }^{4,28}$.

When there is dental agenesis and minimal space between the present teeth, the overall appearance may be satisfactory. In many of these cases, no intervention is required. Light-cured composites can be used to close small diastemata. When the lateral incisors are missing, the spaces of these teeth may be occupied by the canines, which can be transformed into lateral incisors through resin restoration; another option is to gain space for prosthetic substitution, e.g., with a removable partial denture, fixed partial denture, adhesive-fixed partial denture, or implants $4,10,28$.

In the clinical case reported herein, the treatment strategy proposed and adopted consisted of surgical extraction of the supernumerary tooth, primary maxillary canines, and primary right maxillary lateral incisor, to make room for eruption of the permanent teeth. Maintenance of the supernumerary tooth could have interfered with proper eruption and positioning of the adjacent canine. Furthermore, due to agenesis of the left lateral incisor, eruption of the supernumerary tooth would have led to esthetic disharmony in the anterior zone. Therefore, we believed that removal of the supernumerary tooth and esthetic restoration of the canines would provide a more satisfactory outcome.

After eruption of the canines, they were transformed into lateral incisors by light-cured composite resin restoration. The patient was then referred for orthodontic assessment to address the spaces corresponding to the mandibular premolars. As absence of the maxillary lateral incisors and presence of a supernumerary tooth were detected, interceptive orthodontic treatment for space closure was possible.

This treatment was based on the fact that the patient had adequate growth potential and the available space in the dental arch was sufficient for proper canine positioning. The latter was facilitated by the fact that the canines were undergoing active eruption.

A need for orthodontic referral was identified in this case. The purpose of orthodontic assessment was to enable further treatment planning for posterior crossbite correction and management of the absent mandibular second premolars. The practitioner in charge of the case was tasked with informing the patient and her guardian of the proper treatment course. In this regard, the expectations and interests of the patient's guardians regarding the outcome of treatment were the determinants of the results achieved to date.

Several clinical presentations of concomitant hypo-hyperdontia have been described in the literature, and a wide range of treatment approaches have been proposed. The patient described herein presented with a specific clinical form of this anomaly, with unique characteristics regarding the missing teeth and the location of the supernumerary tooth. Within this context, this report sought to contribute to the knowledge of dental practitioners who may encounter similar cases of concomitant hypo-hyperdontia in clinical practice.

\section{CONCLUSION}

According to the literature reviewed, hypohyperdontia in pediatric patients is a rare finding. Dental practitioners involved in the care of children must be 
capable of identifying this anomaly of tooth number and devising a treatment strategy consistent with the clinical presentation. Furthermore, it is imperative that hypohyperdontia be diagnosed as early as possible to minimize potential damage from this anomaly. Management should be multidisciplinary and based on the needs and expectations of patients and their guardians.

\section{REFERENCES}

1. Zhu JF, Marcushamer M, King DL, Henry RJ. Supernumerary and congenitally absent teeth: a literature review. J Clin Pediatr Dent. 1996;20(2):87-95

2. Zhu JF, Crevoisier R, Henry RJ. Congenitally missing permanent lateral incisors in conjuction with a supernumerary tooth: Case report. Pediatr Dent. 1996;18(1):64-6.

3. Laskaris G. Atlas colorido de doenças bucais da infância e adolescência. Porto Alegre: Artmed; 2000.

4. Dhanrajani PJ. Hypodontia: Etiology, clinical features, and management. Quintessence Int. 2002;33(4):294-302.

5. Farias LAG, Simões $W$, Bozzo RO, Oliveira PA. Prevalência da agenesia dentária de jovens do gênero feminino. RGO, Rev Gaúch Odontol. 2006;54(2):115-8.

6. Paula AFB, Ferrer KJN. Prevalência de agenesia em uma clínica ortodôntica de Goiânia. RGO, Rev Gaúch Odontol. 2007;55(2):149-53.

7. Gibson ACL. Concomitant hypo-hyperodontia. $\mathrm{Br} J$ Orthod. 1979;6(2):101-5

8. Hobkirk JA, Brook AH. The management of patients with severe hypodontia. J Oral Rehabil. 1980;7(4):289-98.

9. Townsend G, Rogers J, Richards L, Brown T. Agenesis of permanent maxillary lateral incisors in South Australian twins. Aust Dent J. 1995;40(3):186-92. doi: 10.1111/j.1834-7819.1995.tb05635.x

10. Pinto AS, Raveli DB, Chiavini PCR, Paulin RF, Jacob HB. Tratamento da ausência congênita de incisivo lateral superior por meio da recuperação de espaço para a colocação de implante dentário ou fechamento de espaços: relato de casos. Rev Dental Press Ortodon Ortop Facial. 2002;7:65-77.

11. Spyropoulos ND, Patsakas AJ, Angelopoulos AP. Simultaneous presence of partial anodontia and supernumerary teeth. Oral Surg Oral Med Oral Pathol. 1979;48(1):53-6.

12. Whittington BR, Durward CS. Survey of anomalies in primary teeth and their correlation with the permanent dentition. $\mathrm{N} \mathrm{Z}$ Dent J. 1996;92(407):4-8.

13. Segura JJ, Jimenez-Rubio A. Concomitant hypohyperdontia: simultaneous occurrence of a mesiodens and agenesis of a maxillary lateral incisor. Oral Surg Oral Med Oral Pathol Oral Radiol Endod. 1998;86(4):473-5. doi:10.1016/S10792104(98)90377-8

\section{Collaborators}

HC Ruschel collected clinical material and participated in manuscript writing. M DIAMANTE treated the patient described in the case report and participated in literature review and manuscript writing. PF Kramer directed clinical care of the patient.

14. Regezi JA, Sciubba JJ. Patologia bucal: correlações clinicoPATOLÓGICAS. 3rd ed. Rio de Janeiro: Guanabara Koogan; 2000.

15. Matsumoto $M$, Nagakawa $Y$, Sobue $S$, Ooshima T. Simultaneous presence of a congenitally missing premolar and supernumerary incisor in the same jaw: report of case. ASDC J Dent Child. $2001 ; 68(1): 63-6$

16. Camilleri GE. Concomitant hypodontia and hyperdontia: case report. Br Dent J. 1967;123(7):338-9.

17. Werther R, Rothenberg F. Anodontia. Am J Orthod. 1939;25:61-81.

18. Niswander JD, Sujaku C. Congenital anomalies of teeth in Japanese children. Am J Phys Anthropol. 1963;21:569-74. doi: 10.1002/ajpa.1330210413

19. Horowitz JM. Aplasia and malocclusion: a survey and appraisal. Am J Orthod. 1966; 52(6):440-53. doi: 10.1016/0002-9416(66)90122-9

20. Novak J. Bilateral occurrence of a supernumerary deciduous and permanent canine tooth. Cesk Stomatol. 1974;74(2):148-52.

21. Davis PJ. Hypodontia and hyperdontia of permanent teeth in Hong Kong schoolchildren. Community Dent Oral Epidemiol. 1987;15(4):218-20. doi: 10.1111/j.1600-0528.1987.tb00524.x

22. Tyrologou S, Koch G, Kurol J. Location, complications and treatment of mesiodentes-a retrospective study in children. Swed Dent J. 2005;29(1):1-9.

23. Low T. Hypodontia and supernumerary tooth: report of a case and its management. Br J Orth. 1977;4(4):187-90.

24. Moore R. Hypo-hyperdontia: report of a rare case. Br J Orthod. 1980;7:95-6

25. Sharma A. A rare non-sindrome case of concomitant multiple supernumerary teeth and partial anodontia. J Clin Pediatr Dent. 2001;25(2):167-9. doi:10.17796/jcpd.25.2.k4617k5126205k46

26. Anthonappa RP, Lee CK, Yiu CK, King NM. Hypohyperdontia: literature review and report of seven cases. Oral Surg Oral Med Oral Pathol Oral Radiol Endod. 2008;106(5):e24-30. doi: 10.1016/j.tripleo.2008.07.012

27. Ranta R. Numeric anomalies of teeth in concomitant hypodontia and hyperdontia. J Craniofac Genet Dev Biol. 1988;8(3):45-51.

28. Millar BJ, Taylor NG. Lateral thinking: The management of missing lateral incisors. Br Dent J. 1995;179(3):99-106.

Received on: 21/8/2013

Final version resubmitted on: 7/3/2014

Approved on: 10/6/2014 